\section{'Florida Fry': A Bronze Muscadine Grape}

\author{
J.A. Mortensen ${ }^{1}$, J.W. Harris ${ }^{2}$, and D.L. Hopkins ${ }^{3}$ \\ Central Florida Research and Education Center, University of Florida, 5336 \\ University Avenue, Leesburg, FL 34748
}

Additional index words. Vitis rotundifolia, fresh fruit, fruit breeding, disease resistance

'Florida Fry' (Vitis rotundifolia Michx.) is being released by the Univ. of Florida. It is similar to 'Fry' (Mortensen and Andrews, 1981), but it is hermaphroditic, which will increase productivity, and has a higher level of resistance to fungal diseases. The release also ripens over a long period.

\section{Origin}

'Florida Fry' was one of 136 segregants from a 1983 cross between 'Triumph' and Fla. AD3-42 (Fig. 1). 'Triumph' is hermaphroditic and produces large, bronze fruit with good texture and flavor. Fla. AD3-42 is hermaphroditic and produces medium-sized, bronze fruit with uniform ripening and resistance to ripe rot [Glomerella cingulata (Stonem.) Spaulding \& VonSchrenk] and bitter rot [Melanconium fuligineum (Scrib. \& Viala) Cav.]. The original seedling of 'Florida Fry' was planted in the experimental vineyard in 1985 and first fruited in 1987. This selection, Fla. AA7-44, was chosen in 1987 because of the firm texture, delicious flavor, and good appearance of its fruit, as judged by us.

\section{Description}

The bronze, spherical fruit normally are borne on the third and fourth nodes of the shoot, while occasional fruit may be found on the fifth node (Fig. 2). Clusters are moderately loose, averaging 6.3 berries per cluster. Berry weight is $2.0 \mathrm{~g}$ less than for 'Fry' (Table 1). With an average of 3.5 seeds per berry weighing $8.1 \mathrm{~g}$ per 100 seeds, there is an average flesh : seed ratio of 28:1. Although the flesh : seed ratios of 'Fry' (37:1), 'Summit' (36:1), and 'Triumph' (37:1) are higher than those of 'Florida Fry', the skin is included with the flesh in determining these ratios, and the skin is much thicker on 'Fry' $(2.20 \mathrm{~mm})$, 'Summit' $(1.95 \mathrm{~mm})$, and 'Triumph' (1.10 mm) than on 'Florida Fry' ( $0.87 \mathrm{~mm})$. Pulp of 'Florida Fry'

Received for publication 22 Feb. 1994. Accepted for publication 21 June 1994. University of Florida Agricultural Experiment Station Journal Series paper no. R-03680. The cost of publishing this paper was defrayed in part by the payment of page charges. Under postal regulations, this paper therefore must be hereby marked advertisement solely to indicate this fact.

${ }^{1}$ Professor Emeritus.

${ }^{2}$ Senior Lab Technician.

${ }^{3}$ Professor of Plant Pathology. umph' and, along with its edible skin, breaks up easily when chewed. Berries ripen over an extended period, making 'Florida Fry' a good cultivar for pick-your-own operations. Average ripening date at Leesburg is 19 Aug. At harvest, $\approx 75 \%$ of the stem scars are dry. 'Florida is firmer than that of 'Fry', 'Summit', or 'Tri-

Fig. 2. Fruiting vine of 'Florida Fry'.
Fry' is hermaphroditic and, therefore, may be planted in commercial block plantings or in dooryard plantings, without the need of another cultivar as a pollinizer.

Symptoms of Pierce's disease (Xylella fastidiosa Wells et al.) (Mortensen et al., 1977) have never been observed in 'Florida Fry' plants at Leesburg. Evaluations of harvested fruit have shown it to be more resistant to ripe rot, bitter rot, and black rot [Guignardia bidwellii (Ellis) Viala \& Ravaz f. muscadinii] than 'Fry', 'Triumph', and 'Summit'. Lateseason diseases such as angular leaf spot (Mycosphaerella angulata Jenkins) may occur on 'Florida Fry' but can be controlled by fungicides.

'Florida Fry' is well suited for fresh fruit. Replicated trials evaluating yield of 'Florida Fry' have not been conducted, but individual vines of 'Florida Fry' have outyielded 'Fry', which averaged $8.7 \mathrm{t}^{-} \mathrm{ha}^{-1}$ in a 5-year replicated

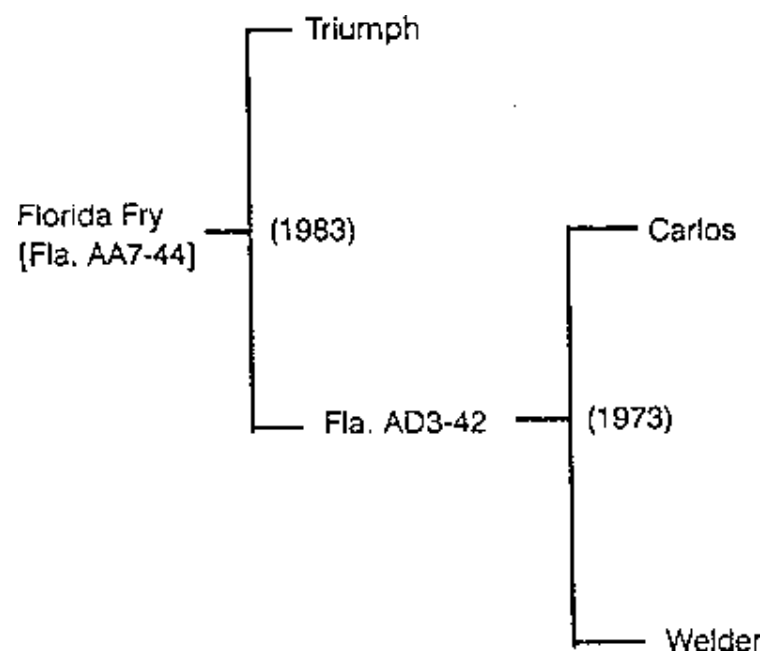

Fig. 1. Pedigree of 'Florida Fry' with year of pollination in parentheses.

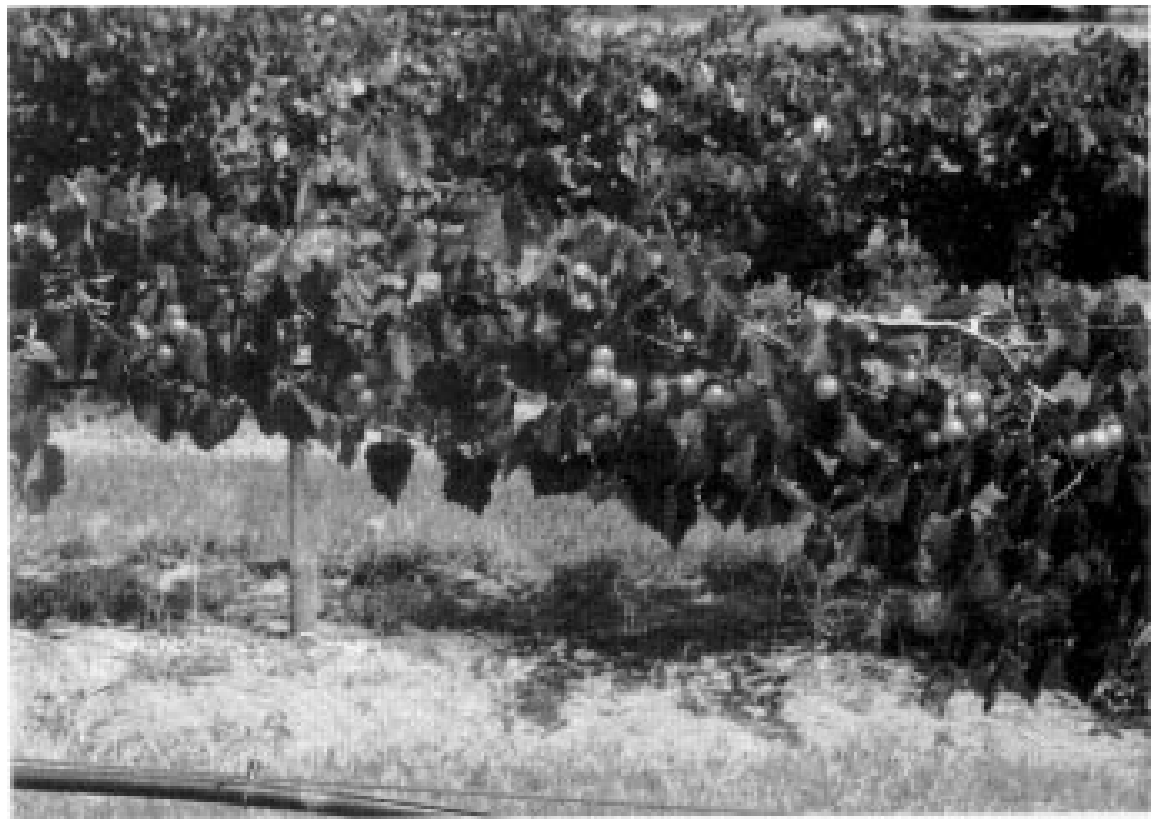


Table 1. Flower type and fruit attributes of 'Florida Fry' compared with three bronze muscadine cultivars grown for fresh-fruit consumption. ${ }^{z}$

\begin{tabular}{lccccc}
\hline \hline & $\begin{array}{c}\text { Fruit with } \\
\text { dry scar } \\
(\%)\end{array}$ & $\begin{array}{c}\text { Berry } \\
\mathrm{wt} \\
(\mathrm{g})\end{array}$ & $\begin{array}{c}\text { Soluble } \\
\text { solids } \\
\text { concn } \\
(\%)\end{array}$ & $\begin{array}{c}\text { Type of } \\
\text { ripening }\end{array}$ \\
\hline Fultivar & $\begin{array}{c}\text { Flower } \\
\text { type }^{\mathrm{y}}\end{array}$ & $76.7 \mathrm{~b}$ & $9.9 \mathrm{~b}$ & $19.1 \mathrm{ab}$ & Uneven \\
Fry & $\mathrm{P}$ & $23.4 \mathrm{c}$ & $11.9 \mathrm{a}$ & $18.2 \mathrm{~b}$ & Uneven \\
Triumph & $\mathrm{F}$ & $95.0 \mathrm{a}$ & $9.2 \mathrm{~b}$ & $18.5 \mathrm{~b}$ & Uneven \\
Summit & $\mathrm{P}$ & $86.7 \mathrm{ab}$ & $9.7 \mathrm{~b}$ & $19.8 \mathrm{a}$ & Even \\
\hline
\end{tabular}

${ }^{2}$ Data are the means for 2 years and represent 30 samples per year for dry scar and berry size and five samples per year for soluble solids. Mean separation within columns by Duncan's multiple range test, $P \leq 0.05$.

${ }^{y} \mathrm{P}=$ perfect $; \mathrm{F}=$ female (pistillate), requiring pollinizer.

test. 'Florida Fry' grows less vigorously than 'Fry' and can be spaced closer together in the row to increase yields per acre (e.g., $3.7 \mathrm{~m}$ apart instead of 4.9 or $5.5 \mathrm{~m}$ ). The cold hardiness of 'Florida Fry' has not been determined, but satisfactory budbreak has occurred with the limited chilling at Leesburg, and young vines are doing well in other southern states.
'Florida Fry' propagates readily from herbaceous cuttings under mist and does not require grafting.

The principal advantages of 'Florida Fry' are perfect flowers, improved resistance to

\section{Summary}

fruit rots, fresh-fruit quality, extended ripening, and relatively dry picking scar (Table 1). The firmer-than-usual muscadine texture with an edible skin likely will make it useful as a commercial fresh-fruit cultivar, especially in the pick-your-own market.

\section{Availability}

Inquiries regarding the availability of 'Florida Fry' should be directed to Florida Foundation Seed Producers, P.O. Box 309, Greenwood, FL 32443.

\section{Literature Cited}

Mortensen, J.A. and C.P. Andrews. 1981. Grape cultivar trials and recommended cultivars for Florida viticulture. Proc. Fla. State Hort. Soc. 94:328-331.

Mortensen, J.A., L.H. Stover, and C.F. Balerdi. 1977. Sources of resistance to Pierce's disease in Vitis. J. Amer. Soc. Hort. Sci. 102:695-697. 